\title{
Awareness about Life-style Modification in Hypertensive Patients Residing in Natore District, Bangladesh
}

\author{
Sumanta Kumer Saha, ${ }^{1}$ Md. Ruhul Amin, ${ }^{2}$ Md Asadul Millat, ${ }^{3}$ Ramendra Nath Sarker ${ }^{4}$
}

\begin{abstract}
Objective: For better control of hypertension, behavior (knowledge, attitude and practice) of hypertensive patients about life-style change is essential. This study was done to determine the level of knowledge, attitude and practice of hypertensive patients regarding life-style change needed to control of hypertension.

Methods: The present cross-sectional study was conducted in Natore General Hospital, Natore over a period of 4 months from September to December, 2015. A total of 50 adult hypertensive patients suffering from the disease for at least six months were included in the study. Of them 20 were selected from patients attending at the Outpatient Department of Medicine, Natore General Hospital and 30 were selected by snowballing. Data were collected using a semi-structured questionnaire and the levels of knowledge and practice status were measured on Likert Scale (0-4). Score ' 1 ' was assigned for each correct answer and score ' 0 ' for each wrong answer, except for two knowledge-related questions where highest score was ' 2 ' and the lowest was ' 0 '. As there were more than one question in assessing respondents' perception and practice, combined scores were used to measure the intended behaviour.

Results: The result showed that about two-thirds $(66 \%)$ of the respondents lie between $4^{\text {th }}$ and $5^{\text {th }}$ decades of life with mean age being 48.4 years (range: 17 - 80 ears). Male to female ratio was roughly $1: 1$. Majority (96\%) of the respondents was married. Primary level educated formed about one-third (32\%) of the respondents followed by HSC (20\%), graduation $(18 \%)$ and illiterate $(16 \%)$. Nearly half $(46 \%)$ of the respondents was poor. Seventy percent of the respondents' blood pressure was beyond control at the time of interview with mean systolic and diastolic blood pressures being 140 and 92 $\mathrm{mmHg}$ respectively. More than half $(54 \%)$ of the respondents' duration of hypertension was $<5$ years with median duration being 3 years. Over one-quarter (28\%) was adequately aware and two-thirds (68\%) were partially aware of lifestyle modification and most ( $88 \%)$ of the respondents' source of information was doctor. Although majority ( $84 \%)$ was informed of life-style change from their doctors, only $28.6 \%$ of them considered those advices to be adequate to bring about effective change in their life-style. Majority ( $92 \%)$ held the view that additional salt to be avoided followed by smoking cessation or tobacco chewing $(88 \%)$, diet control $(84 \%)$ and having regular exercise (82\%). A substantial proportion (72\%) also put emphasis to weight reduction. In terms of practice, over two-thirds (70\%) adopted change in their life-style to control blood pressure. Of them $20(57.1 \%)$ were practicing diet control, another 20(57.1\%) avoiding added salt with meals and $10(28.5 \%)$ quitted smoking for reducing the chance of having heart attack or stroke in future. Ten $(20 \%)$ respondents were used to smoking at the time of interview. Of them $7(70 \%)$ intended to give up the habit. Half $(52 \%)$ of the respondents took exercise but the rate of performing regular exercise (5 days in a week) was only $19.3 \%$. Those who were not used to taking exercise, $16.7 \%$ of them told that they did not have spare time to have exercise, about $30 \%$ told that the role of exercise on blood pressure control was not known to them, another $30 \%$ tried but failed to continue and $20.8 \%$ were reluctant to take exercise. More than half (56\%) of the respondents' level of knowledge was satisfactory, followed by $30 \%$ more or less satisfactory and $14 \%$ poor. However, about one-third (32\%) of the respondents' practice level was satisfactory, $34 \%$ more or less satisfactory, $24 \%$ poor, $8 \%$ very poor and only $2 \%$ highly satisfactory.

Conclusion: The knowledge level of hypertensive patients about their life-style change is far below the desired level. The practice level is even low meaning that not all the respondents having knowledge about life-style modification translated the same into practice This indicates that there lies a gap between perception \& practice which act as a barrier to motivation.

Key words: Hypertensive, hypertension, life-style modification, knowledge and behavior etc.
\end{abstract}

\section{Authors' information:}

${ }^{7}$ Dr. Sumanta Kumer Saha, Assistant Professor, Holy Family Red Crescent Medical College, Dhaka.

${ }^{2}$ Dr. Md. Ruhul Amin, MBBS, MPH (DU), DCH (BSMMU), Assistant Professor, Department of Paediatrics, Rangpur Medical College Hospital, Rangpur.

${ }^{3}$ Dr. Md Asadul Millat, Senior Consultant (Cardiology), Mugda Medical College \& Hospital, Dhaka.

${ }^{3}$ Dr. Ramendra Nath Sarker, D Card (BSMMU), Senior Consultant (Cardiology), District Hospital Gaibandha.

Correspondence: Dr. Sumanta Kumer Saha, Cell Phone: +8801729097404 E-mail:saha0018@gmail.com 


\section{INTRODUCTION:}

Hypertension is the commonest cardiovascular disorder, posing a major public health challenge to population in which socioeconomic and epidemiological transition is going on. It is one of the major risk factors for cardiovascular mortality, which accounts for $20-50 \%$ of all deaths. ${ }^{1}$ Although it is an emerging epidemic worldwide, awareness against it is very poor. So are treatment \& control measures taken. The $7^{\text {th }}$ Joint National Committee on prevention, detection, evaluation, and treatment of high blood pressure (BP) strongly advocated lifestyle and behavioral modifications as a cost-effective strategy for controlling hypertension in the community. But still there are some barriers that prevent people from adopting a healthy life-style which can be overcome by constant encouragement, support, and appropriate education to the people. ${ }^{2}$

The adoption of a healthy lifestyle is of utmost importance for preventing and managing hypertension. According to the JNC 7 guidelines, all patients with hypertension should adopt lifestyle modification strategies regardless of whether they take antihypertensive medications. The components of the lifestyle modifications listed in the JNC 7 guidelines are reducing weight, adopting healthy dietary behavior, reducing dietary sodium intake, engaging in physical activity etc. ${ }^{3-5}$ Each of these components, when adopted, can have an impact on reducing systolic blood pressure (SBP). While in the past diastolic blood pressure (DBP) has been a focus of clinicians, presently systolic blood pressure (SBP) level appears to be a better predictor of cardiovascular disease (CVD). The emergence of hypertension and other CVDs has become a public health problem due to the aging of the populations, urbanization, and socioeconomic changes favoring sedentary habits, obesity, alcohol consumption, and salt intake. ${ }^{6} \mathrm{~A}$ cost-effective use of health services to control these chronic diseases is badly needed in developing countries where resources to curb this public health menace are limited.
Faced with this context, hypertension presents a major area of intervention because it is rampantly prevailing condition and is amenable to control through both lifestyle modification and pharmacological treatment. Pharmacological treatment for hypertension has been shown to be effective in decreasing blood pressure, ${ }^{7}$ but life-style change is no less important than control of blood pressure. Lifestyle interventions also have the potential to reduce the need for or the amount of medications in hypertensive and prevent high BP from developing in nonhypertensive. Several models have been proposed regarding health behaviors and sustained life-style changes. ${ }^{8-10}$ Although they may differ in content and perspective, models for life-style change stress the importance of perceptions, attitudes, practices about life-style modification as a crucial means to good hypertension control. A proper assessment of knowledge, attitude and practice (KAP) of the individuals regarding their life-style changes will, therefore, be of immense help in future planning for controlling of hypertension in the community. ${ }^{11}$ The present study intended to assess the level of knowledge and practice about life-style modification among the hypertensive patients is, therefore, justified.

\section{METHODS:}

The present cross-sectional study was conducted in Natore General Hospital over a period of 4 months from September to December, 2015. Adult hypertensive patients ranging from 19-69 years and suffering from hypertension for at least six months were eligible for study. A total of 50 such patients were included in the study. Of them 20 were selected from patients attending at the Outpatient Department of Medicine, Natore General Hospital. Taking information from them, the rest 30 were selected by snowballing. Data were collected using a semi-structured questionnaire containing the variables of interest. Collected data were processed and analyzed using SPSS (Statistical Package for Social Science), version 17. Data presented in categorical scale were presented as frequency and corresponding 
percentage, while the data presented on continuous scale were expressed as mean, median and standard deviation. The level of knowledge and practice status were measured on Likert Scale (0-4). Score ' 1 ' was assigned for each correct answer and score ' 0 ' for each wrong answer, except for two knowledge-related questions where highest score was ' 2 ' and the lowest was ' 0 '. As there were more than one question in assessing respondents' perception and practice, combined scores were used to measure the perception and practice about life-style modification.

\section{RESULTS:}

Age distribution of the respondents shows that about one-third (32\%) was in their $4^{\text {th }}$ decade of life (between 40-50 years of age) and another one-third (34\%) was in their $5^{\text {th }}$ decade of life with mean age being 48.4 (range:19-69) years. Males and females were almost identically distributed (male to female ratio roughly $1: 1$ ). Majority $(96 \%)$ of respondents was married. Primary level educated formed about one-third (32\%) of the respondents followed by HSC (20\%), graduation $(18 \%)$, illiterate $(16 \%)$ and SSC level educated $(6 \%)$. Nearly half (46\%) of the respondents had monthly family income between Tk. 10,00020,000, 24\% Tk. 40,000 or > 40000 (Table I).

About half (46\%) the respondents' BMI was within normal range, followed by $26 \%$ overweight and $22 \%$ obese (Table II). Over one-quarter (26\%) had normal systolic blood pressure ( $<140 \mathrm{mmHg}$ ) and $24 \%$ had blood pressure $\geq 170 \mathrm{mmHg}$. In case of diastolic blood pressure $46 \%$ had $90-99 \mathrm{mmHg}$ and $34 \%$ had $80-89 \mathrm{mmHg}$. More than half (54\%) of the respondents' duration of hypertension was less than 5 years followed by $24 \% 5-10$ years, $12 \% 10-15$ years, $6 \% 20$ or $>20$ years and $4 \%$ 15-20 years with median duration being 3 years (range: $1-30$ years) (Table III). Majority (68\%) of respondents was partially aware of lifestyle modification needed to control hypertension and $28 \%$ had adequate knowledge about the same issue. Most ( $88 \%$ ) of the respondents' source of information was doctor, followed by radio and TV
(50\%). Print media and friends' contribution to respondents' knowledge were $44 \%$ and $42 \%$ respectively. Regarding components of life-style modification, majority (92\%) held the view that additional salt to be avoided followed by smoking cessation (88\%), giving up tobacco chewing $(84 \%)$, diet control (84\%) and having regular exercise ( $82 \%)$. A substantial proportion (72\%) also put emphasis to weight reduction and avoidance of alcohol (Table IV). Majority (84\%) informed that their doctor advised them to life-style change but only $28.6 \%$ of them considered those advices adequate to bring about effective change in the life-style. Sixty percent opined that they thought lifestyle modification could be useful in controlling blood pressure. Over two-thirds (70\%) informed that they adopted change in their life-style to control blood pressure. Of them 20(57.1\%) were practicing diet control, another $20(57.1 \%)$ avoiding added salt with meals and $10(28.5 \%)$ quitted smoking (Table V). Table VI shows that $10(20 \%)$ respondents were used to smoking at the time of interview. Of them $2(20 \%)$ had 5 or $<5$ years, $2(20 \%) 5-10$ years, $1(10 \%) 10-20$ years, $3(30 \%) 20-30$ years and $2(10 \%) 30-40$ years of smoking habit. Half (50\%) of the smokers smoked 10-20 sticks a day and $40 \% 10$ or < 10 sticks a day. Seventy percent of the smokers intended to give up smoking. Of the respondents who did not think of quitting smoking $(n=3), 2(66.7 \%)$ argued that smoking relives stress \& 1(33.3\%) told that withdrawal symptoms are too hard to cope with. In response to a question why they quitted smoking, $85.7 \%$ informed that quitting smoking would reduce the chance of heart attack or stroke, $71.4 \%$ for family or peer pressure, $14.2 \%$ due to experience of a heart attack. Over half (52\%) of the respondents took exercise and among them $65.4 \%$ were practicing it regularly. Nearly half $(46.1 \%)$ used to take exercise 7 days a week, 23.1\% 6 days a week, $19.3 \% 5$ days a week and $11.5 \% 3$ days a week. Fifty percent took exercise for 30 minutes, 26.9\% for 45 minutes, $15.3 \%$ for 60 minutes and $7.8 \%$ for 20 or $<20$ minutes for each day. Walking was the predominant type of exercise (92.3\%) 
performed by the respondents followed by free-hand exercise (23.1\%). Playing outdoor games and running each comprised $3.8 \%$. Investigating about reasons of avoiding exercise, $16.7 \%$ respondents told that they did not have spare time to have exercise, $29.1 \%$ told that role of exercise on blood pressure control was not known to them, another $29.1 \%$ tried but failed to stick to exercise \& $20.8 \%$ were reluctant to take exercise (Table VII). According to Likert Scale, more than half $(56 \%)$ of the respondents' level of knowledge was satisfactory, followed by $30 \%$ more or less satisfactory and $14 \%$ poor knowledge (Fig 1). Based on the Likert Scale scoring for measuring practice level, about one-third (32\%) of the respondents' practice level was satisfactory, 34\% were more or less satisfactory, $24 \%$ poor, $8 \%$ very poor and only $2 \%$ highly satisfactory (Fig 2 ).

\begin{tabular}{|c|c|c|}
\hline Demographic characteristics & Frequency & Percentage \\
\hline \multicolumn{3}{|l|}{ Age (years) } \\
\hline$<30$ & 3 & 6.00 \\
\hline $30-40$ & 6 & 12.00 \\
\hline $40-50$ & 16 & 32.00 \\
\hline $50-60$ & 17 & 34.00 \\
\hline$\geq 60$ & 8 & 16.00 \\
\hline \multicolumn{3}{|l|}{ Sex } \\
\hline Male & 24 & 48.0 \\
\hline Female & 26 & 52.0 \\
\hline \multicolumn{3}{|l|}{ Marital status } \\
\hline Married & 48 & 96.0 \\
\hline Unmarried & 2 & 4.0 \\
\hline \multicolumn{3}{|l|}{ Level of education } \\
\hline Never been to school & 8 & 16.00 \\
\hline Primary & 16 & 32.00 \\
\hline SSC & 3 & 6.00 \\
\hline HSC & 10 & 20.00 \\
\hline Graduation & 9 & 18.00 \\
\hline Post-graduation & 4 & 8.00 \\
\hline \multicolumn{3}{|l|}{ Monthly income (Tk.) } \\
\hline$<10000$ & 3 & 6.00 \\
\hline $10000-20000$ & 23 & 46.00 \\
\hline $20000-30000$ & 8 & 16.00 \\
\hline $30000-40000$ & 4 & 8.00 \\
\hline$\geq 40000$ & 12 & 24.00 \\
\hline
\end{tabular}

*Mean age $=(48.4 \pm 11.9)$ yrs.; range $=(19-69)$ yrs.

*Median income $=(25200 \pm 21424) \mathrm{Tk}$; range $=(1000-100000) \mathrm{Tk}$.

\begin{tabular}{|c|c|c|}
\hline BMI $\left(\mathrm{kg} / \mathrm{m}^{2}\right)$ & Frequency & Percentage \\
\hline <18.5 (Underweight) & 2 & 4.00 \\
\hline 18.5 - 24.9 (Normal) & 23 & 46.00 \\
\hline $25-29.9$ (Overweight) & 13 & 26.00 \\
\hline $30-39.9$ (Obese) & 11 & 22.00 \\
\hline$\geq 40$ (Morbid) & 1 & 2.00 \\
\hline
\end{tabular}

TABLE III. Distribution of respondents by blood pressure $(n=50)$

$\begin{array}{lcc}\text { Blood pressure } & \text { Frequency } & \text { Percentage } \\ \begin{array}{l}\text { Level of blood pressure }(\mathrm{mmHg}) \\ \text { Systolic blood pressure }\end{array} & & \\ \quad<140 & 13 & 26.0 \\ 140-149 & 10 & 20.0 \\ 150-159 & 7 & 14.0 \\ 160-169 & 7 & 14.0 \\ \geq 170 & 12 & 24.0 \\ \text { Diastolic blood pressure } & & \\ \quad<80 & 2 & 4.00 \\ 80-89 & 17 & 34.00 \\ 90-99 & 23 & 46.00 \\ 100-109 & 2 & 4.00 \\ \geq 110 & 5 & 10.00 \\ \text { Duration of hypertension* (years) } & & \\ <5 & 27 & 54.00 \\ 5-10 & 12 & 24.00 \\ 10-15 & 6 & 12.00 \\ 15-20 & 2 & 4.00 \\ \geq 20 & 3 & 6.00\end{array}$

Mean systolic BP $=(140 \pm 20) \mathrm{mmHg}$ and mean diastoloic $\mathrm{BP}=(92 \pm 20) \mathrm{mmHg}$. *Median duration(range) of blood pressure $=3($ range: $1-30)$ years.

$\begin{array}{lcc}\begin{array}{l}\text { TABLE IV. Respondents' source of knowledge about lifestyle } \\ \text { change ( } \mathbf{n}=\mathbf{5 0} \text { ) }\end{array} & \text { Frequency } & \text { Percentage } \\ \text { Source of knowledge } & & \\ \begin{array}{l}\text { about lifestyle change } \\ \text { knowledge about lifestyle modification }\end{array} & 14 & 28.0 \\ \quad \text { Know } & 34 & 68.0 \\ \quad \text { Partially know } & 2 & 4.0 \\ \quad \text { Don't know } & & \\ \text { Source of knowledge about lifestyle change } & 44 & 88.00 \\ \text { Doctors } & 1 & 2.00 \\ \text { Laymen's knowledge } & 25 & 50.00 \\ \quad \text { Electronic media (TV, radio) } & 22 & 44.00 \\ \text { Print media (newspaper, magazine) } & 1 & 2.00 \\ \text { Internet (web page) } & 21 & 42.00 \\ \text { Friends / peers } & & \\ \text { Components of lifestyle modification } & 46 & 92.0 \\ \text { Avoidance of additional salt } & 44 & 88.0 \\ \text { Smoking cessation } & 42 & 84.0 \\ \text { Giving up tobacco chewing } & 42 & 84.0 \\ \text { Diet control } & 41 & 82.0 \\ \text { Taking regular exercise } & 36 & 72.0 \\ \text { Weight reduction } & 36 & 72.0 \\ \text { Avoiding alcohol } & \end{array}$

*Total will not correspond to 100 percent for multiple responses 


\begin{tabular}{|c|c|c|}
\hline $\begin{array}{l}\text { Perception and practice } \\
\text { about life-style change }\end{array}$ & Frequency & Percentage \\
\hline \multicolumn{3}{|l|}{ Comment about doctors' advice } \\
\hline Advised by doctor $(n=50)$ & 42 & 84.0 \\
\hline Advice adequate $(n=42)$ & 12 & 28.6 \\
\hline \multicolumn{3}{|l|}{$\begin{array}{l}\text { BP control by life-style } \\
\text { modification }(n=50)\end{array}$} \\
\hline Useful & 30 & 60.0 \\
\hline Partially useful & 16 & 32.0 \\
\hline Not useful & 4 & 8.0 \\
\hline \multicolumn{3}{|l|}{ Life-style modification practice: } \\
\hline Adopted life-style modification ( $n=50$ ) & 35 & 70.0 \\
\hline \multicolumn{3}{|l|}{ Pattern of life style modification $(n=35)$} \\
\hline Diet control & 20 & 57.1 \\
\hline Avoided taking added salt with meals & 20 & 57.1 \\
\hline Cessation of smoking & 10 & 28.5 \\
\hline
\end{tabular}

\section{TABLE VI. Distribution of patients by their smoking profile and attitude to smoking}

\begin{tabular}{|c|c|c|}
\hline $\begin{array}{l}\text { Smoking related } \\
\text { variables }\end{array}$ & equency & Percentage \\
\hline \multicolumn{3}{|l|}{ Smoking status $(n=50)$} \\
\hline Smoker & 10 & 20.0 \\
\hline Non-smoker & 40 & 80.0 \\
\hline \multicolumn{3}{|l|}{ Duration of smoking in years $(n=10)$} \\
\hline$\leq 5$ & 2 & 20.0 \\
\hline $5-10$ & 2 & 20.0 \\
\hline $10-20$ & 1 & 10.0 \\
\hline $20-30$ & 3 & 30.0 \\
\hline $30-40$ & 2 & 20.0 \\
\hline \multicolumn{3}{|l|}{ Number of sticks smoked/day $(n=10)$} \\
\hline$\leq 10$ & 4 & 40.0 \\
\hline $10-20$ & 5 & 50.0 \\
\hline $20-30$ & 1 & 10.0 \\
\hline \multicolumn{3}{|l|}{ Thought of quitting smoking $(n=10)$} \\
\hline Yes & 7 & 70.0 \\
\hline No & 3 & 30.0 \\
\hline \multicolumn{3}{|l|}{ Reasons of not quitting smoking $(n=3)$} \\
\hline Smoking relives stress & 2 & 66.7 \\
\hline Withdrawal symptoms are too hard to handle & e 1 & 33.3 \\
\hline \multicolumn{3}{|l|}{ Reasons of quitting smoking $(n=7)$} \\
\hline Experienced a heart attack & 1 & 14.2 \\
\hline Family or peer pressure & 5 & 71.4 \\
\hline Reduce chance of having heart attack or stroke & 6 & 85.7 \\
\hline Other reasons & 4 & 57.1 \\
\hline
\end{tabular}

\begin{tabular}{|c|c|c|}
\hline $\begin{array}{l}\text { Life-style modification } \\
\text { practice }\end{array}$ & Frequency & Percentage \\
\hline \multicolumn{3}{|l|}{ Perform exercise $(n=50)$} \\
\hline Yes & 26 & 52.0 \\
\hline No & 24 & 48.0 \\
\hline Did exercise regularly $(n=26)$ & 17 & 65.3 \\
\hline \multicolumn{3}{|l|}{ Frequency of exercise (days/wk) $(n=26)$} \\
\hline 3 days/week & 3 & 11.5 \\
\hline 5 & 5 & 19.3 \\
\hline 6 & 6 & 23.1 \\
\hline 7 & 12 & 46.1 \\
\hline \multicolumn{3}{|c|}{ Duration of exercise each day $(\mathrm{min})(n=26)$} \\
\hline$\leq 20$ & 2 & 7.7 \\
\hline 30 & 13 & 50.0 \\
\hline 45 & 7 & 26.9 \\
\hline 60 & 4 & 15.5 \\
\hline \multicolumn{3}{|l|}{ Type of exercise $(n=26 *)$} \\
\hline Walking & 24 & 92.3 \\
\hline Running & 1 & 3.8 \\
\hline Free hand exercise & 6 & 23.1 \\
\hline Playing outdoor games & 1 & 3.8 \\
\hline Others exercise & 1 & 3.8 \\
\hline \multicolumn{3}{|l|}{ Reasons of avoiding exercise $\left(n=24^{*}\right)$} \\
\hline No spare time due to job nature & 4 & 16.7 \\
\hline Role in BP control unknown & 7 & 29.1 \\
\hline Tried, but couldn't stick to a routine & 7 & 29.1 \\
\hline Not interested & 5 & 20.8 \\
\hline Other reasons & 1 & 4.1 \\
\hline
\end{tabular}

*Total will not correspond to 100 percent for multiple responses

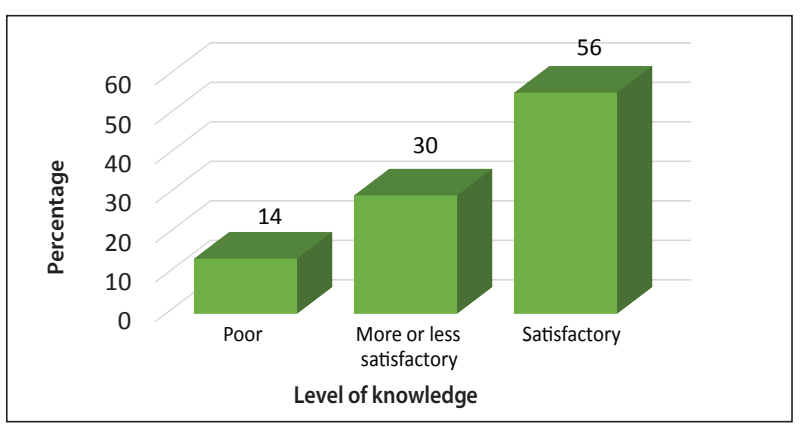

Fig 1. Respondents' knowledge regarding lifestyle modification

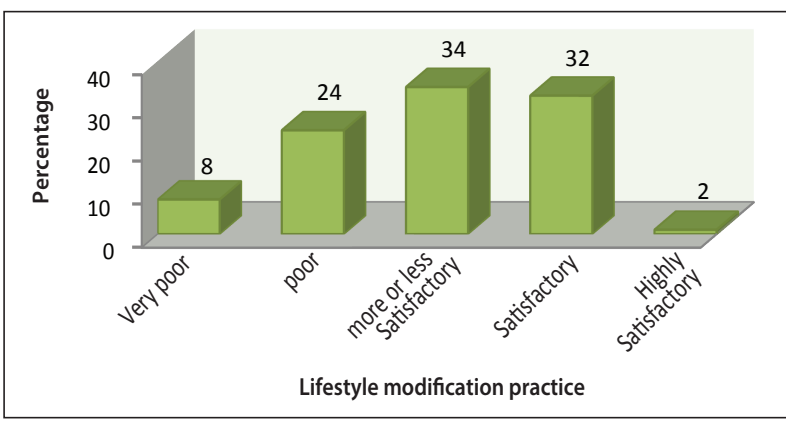

Fig 2. Distribution of respondents by practicing lifestyle modification 


\section{DISCUSSION:}

The present study demonstrated that the over half (56\%) of hypertensive patients had satisfactory and $30 \%$ more or less satisfactory level of knowledgeabout both hyperatension and the effect of a healthy lifestyle on controlling blood pressure. Moreover, $60 \%$ of the respondents fully and $32 \%$ partially believed that their disease could be managed by life-style modification. However, we found that many patients did not lead a healthy lifestyle. Although more than two-thirds of the respondents told that they adopted a healthy life-style, in reality, they all did not comply to all the components of life-style modification. A little more than half $(57.1 \%)$ were practicing diet control and avoiding added salt with meals but only $28.5 \%$ quitted smoking. Although half $(52 \%)$ of the respondents used to perform exercise, performing regular exercise 5 days in a week was much less (19.3\%). Furthermore, only half of the respondents had a body mass index within normal range, while others were overweight or obese. Only one-third (32\%) of the respondents had blood pressure levels within normal range ( $\geq 140 / 90 \mathrm{mmHg}$ ) at the time of interview. These findings suggest that hypertensive patients' lifestyle behaviors are still not up to the expectation and hence the poor control of blood pressure. Data from the U.S. National Health and Nutrition Examination Survey for 1999-2004 show that $65 \%$ of hypertensive patients do not have their blood pressure controlled (below 140/90 mmHg), which could be attributed to poor management of blood pressure. ${ }^{12}$ The non-optimal results among hypertensive patients in Israel could stem from the fact that, only a third to half of the hypertensive patients reported receiving counseling from their physician on the necessity of smoking cessation, correct diet, desired weight, and regular exercise in the treatment of blood pressure ${ }^{11}$ which corresponds well with the findings of the present study.

In the present study majority of the respondents was informed about life-style modification from their physicians, but one-quarter of them considered those advices adequate to bring about a desired change in all the components of life-style modification. Previous studies suggest that knowledge transferred from medical staff is an important factor in inducing patients to comply with lifestyle recommendations. ${ }^{13}$ Nevertheless, similar low counseling rates were reported in studies conducted abroad. ${ }^{14-15}$ The effect of beliefs and knowledge about hypertension and its management is concordant with the known theoretical model relating attitudes to changes in lifestyle behaviors, ${ }^{16}$ as well as findings of previous studies reporting that patients' education about hypertension and lifestyle modification improved blood pressure control. ${ }^{11,17}$ Apparently, such patients can play a more active role in their treatment and are, therefore, more effective in controlling hypertension. The role of physicians in counseling patients' compliance with lifestyle changes is also a tested one. ${ }^{13,18}$ Low counseling rates may be attributed to a lack of time, knowledge, skills and training on lifestyle counseling, leading to physicians' low self-confidence in performing this role. ${ }^{19-21}$

One of the greatest challenges facing medical systems is finding effective strategies for convincing and helping patients with chronic diseases, including hypertension, to change their lifestyle and to play an active part in their treatment. The predominant theory is that there is a need to understand what motivates each patient $\&$ what affects his/her motivation and to convince him/her to make the change accordingly. ${ }^{22,23}$ This can be achieved by organizing patient-centered workshops, for example, to teach about hypertension and to raise the level of patients' motivation to play an active role in their treatment. This will go a long way in empowering patients and making them partners in the management of their condition. However, like any other scientific studies, the present study has several limitations which deserve mention. First, the study was based on self-reporting by patients regarding their lifestyle behaviors and physician recommendations. These may be inaccurate 
because of recall bias or tendency of the patients to hide their practice behaviour. However, as there were no alternative sources of information regarding patients' behaviors and physicians' lifestyle counseling as those were not recorded in the medical files, patients' information should be considered a reliable source of information on such topics. ${ }^{24}$ Secondly, as the data were collected from asecondary level hospital and from the catchment area of that hospital and the sample size was smaller than required the findings cannot be generalized to reference population. Thirdly, as the study was a descriptive one there was no scope to come to a conclusion about the cause (doctors counseling about life-style modification) and the effect (behaviour change on the part of the patients), and therefore we refer only to a case-control study in this regard.

\section{CONCLUSION:}

The knowledge level of hypertensive patients about their life-style modification is far below the desired level. The practice level is even low meaning that not all the respondents having knowledge about life-style modification are practicing the same in their life. This indicates that there lies a gap between knowledge and practice which act as a barrier to motivation.

However, the inadequate counseling by the physicians found in the study suggests that there may be a need to improve physicians' counseling aptitude and skills so that they can confidently deliver this service to their patients.

The present study therefore, recommends study with large sample to identify the gap between knowledge and practice to bring about desired change in the practice level. A model based on educating both physicians and patients may contribute to improving the care of hypertensive patients.

\section{REFERENCES:}

1. Park K, Text Book of Preventive and Social Medicine. 18th edition. Jabalpur: M/S Banarsidas Bhanot Publishers; 2005.
2. Chobanian AV, Bakris GL, Black HR, Cushman WC, Green LA, Lzzo JL Jr, Joint National Committee on Prevention, Detection, Evaluation, and Treatment of High Blood Pressure. National Heart, Lung, and Blood Institute; National High Blood Pressure Education Program Coordinating Committee. Seventh Report of the Joint National Committee on Prevention, Detection, Evaluation and Treatmentof High Blood Pressure. Hypertension 2003; 42:1206. Available from: http:/www.theheart.org/article/ Accessed on 01.01.2013.

3. Cutler JA. Combinations of lifestyle modification and drug treatment in management of mild-moderate hypertension: a review of randomized clinical trials. Clin Exp Hypertens 1993;15:1193-204.

4. Puddey IB, Parker M, Beilin LJ, Vandongen R, Masarei JR. Effects of alcohol and caloric restriction on blood pressure and serum lipids in overweight men. Hypertension 1992;20:533-541.

5. Stevens VJ, Corrigan SA, Obarzanek E, Bernauer E, Cook NR, Hebert P, Mattfeld-Beman M, Oberman A, Sugars C, Dalcin AT. Weight loss intervention in phase 1 of the Trials of Hypertension Prevention. TOHP Collaborative Research Group. Arch Intern Med 1993;153:849-58.

6. Akinkugbe CO. World epidemiology of hypertension in blacks. J Clin Hypeitens 1987;3:1S-8S.

7. Collins $\mathrm{R}$, Peto $\mathrm{R}$, MacMahon $\mathrm{S}$, Hebert $\mathrm{B}$, Fiebach $\mathrm{NH}$, Eberlein KA, Godwin J, Qizilbash N, Taylor JO, Henneckens $\mathrm{CH}$. Blood pressure, stroke, and coronary heart disease, II: short-term reductions in blood pressure: overview of randomised drug trials in their epidemiological context. Lancet 1990;335:827- 38.

8. Rosenstock IM, Strecher VJ, Becker MH. Social learning theory and the health belief model. Health Educ $Q$ 1988;15:175-83.

9. Prochaska J, DiClemente C. Towards a comprehensive model of change. In: Miller W, Heather N, eds. Treating Addictive Behaviors: Processes of Change. New York, NY: Plenum Press; 1986:3-27.

10. Prochaska JO, DiClemente CC, Norcross JC. In search of how people change: application to addictive behaviours. Am Psychol 1992;47:1102-114.

11. Chobanian AV, Bakris GL, Black HR, Cushman WC, Green LA, Izzo JL Jr, Jones DW, Materson BJ, Oparil S, Wright JT Jr, Roccella EJ; Joint National Committee on Prevention, Detection, Evaluation, and Treatment of High Blood Pressure. National Heart, Lung, and Blood Institute; National High Blood Pressure Education Program Coordinating Committee.seventh report of the Joint National Committee on Prevention, Detection, Evaluation, and Treatment of High Blood Pressure. Hypertension 2003;42(6):1206-52.

12. Chobanian AV. The hypertension paradox-more uncontrolled disease despite improved therapy. NEJ Med 2009;361:878-87. 
13. Hroscikoski MC, Solberg LI, Sperl-Hillen JM, Harper PG, McGrail MP, Crabtree BF. Challenges of change: a qualitative study of chronic care model implementation. Ann Fam Med 2006;4:317-26.

14. Stange KC, Flocke SA, Goodwin MA, Kelly RB, Zyzanski SJ. Direct observation of rates of preventive service delivery in community family practice. Prev Med 2000; 31:167-71.

15. Stafford RS. National patterns of physician activities related to obesity management. Arch Fam Med 2000; $9(7): 631-8$.

16. Galuska DA, Will JC, Serdula MK, Ford ES. Are health care professionals advising obese patients to lose weight? JAMA 1999;282(16):1576-8.

17. Roumie CL, Elasy TA, Greevy R, Griffin MR, Liu X, Stone WJ, Wallston KA, Dittus RS, Alvarez V, Cobb J, Speroff T. Improving blood pressure control through provider education, provider alert and patient education. Ann Intern Med 2006;145(3):165-75.

18. Thorogood $M$, Hillsdon $M$, Summerbell $C$. Changing behaviour [Review]. Din Evid 2003;10:95-117.
19. Cabana MD, Rand CS, Powe NR, Wu AW, Wilson $M H$, Abboud PA, Rubin HR. Why don't physicians follow clinical prac $\neg$ tice guidelines? A framework for improvement. JAMA 1999:282(15):1458-65.

20. Cornuz J, Ghali WA, Di Carlantonio D, Pecoud A, Paccaud F. Physicians' attitudes towards prevention: importance of intervention-specific barriers and physicians' health habits. Fam Pract 2000;17:535-40.

21. Huang J, Yu H, Marin E, Brock S, Garden D, Davis T. Physicians' weight loss counseling in two public hospital primary care clinics. Acad Med 2004;79(2):156-61.

22. Lehdenpera $T$, Kyngas $H$. Levels of compliance shown by hypertensive patients and their attitude toward their illness. J Adv Nurs 2001;34(2):189-95.

23. Simon C, Chabrier G. How to prescribe physical activity in clinical practice. Ann Endocrinol (Paris) 2005;66: 2S29-35.

24. Kaplan SH, Ware EF. The patient's role in health care and quality assessment. In: Goldfield N, Nash DB, eds. Managing Quality of Care in a Cost-focused Environment Tampa, FL: Aspen Publications 1999:13-55. 